\title{
KAJIAN SATYA LAKSANA BIMA TERHADAP GURU DRONA MASIH RELEVAN SEBAGAI NILAI PENDIDIKAN KARAKTER DALAM CERITA WAYANG LAKON DEWA RUCI
}

Oleh :

\author{
I Wayan Surija \\ (E-mail: iwayan.surija@gmail.com) \\ Ni Wayan Purnamiasih \\ (E-mail : yanasihpriyatama@gmail.com) \\ I Gusti Ngurah Rai \\ Drs. AA.Raka Mas
}

\begin{abstract}
This researcher discusses the educational values of satya against Bima where the Bima characters in the mahabarata puppet play of the god ruci. This theme was taken because of interest in Bima's character in the Mahabarta puppet. Behind the arrogant, hard and arongan figure, Bima has a good heart, reverend officers truth, honesty, sincerity, devotion to teachers, sradha or beliefs, good morals and strong mentality these qualities are found in the soul of Bima where this trait can be something that is very relevant at present in the world of education. In aspects of honesty Bima really has an honest heart to anyone, in his time Bima kneels knowledge to his teacher Drona he is very honest with his teacher. From the aspect of sincerity, Bima was very sincere in accepting what was assigned to his teacher for the sake of addressing devotion to the teacher in chess teacher devotion to the teacher of teaching, metal asepek was very important in an education where strong mentality would make a success in what tasks also. In moral asepek is an equally important asepek where moral is part of ethics and manners and discipline in taking an education. These values are what we need to exemplify for the younger generation in education today, where today the values of mental, moral, honesty, sincerity and sradha are low. When Bima was instructed by his teacher Drona to look for water, we were in the middle the sea, Bima holds the traits that are in him, namely sincere, mental, moral, honest, sradha or belief in this matter. Bima holds firm for a success in a test from his teacher. This study is a literature study using document or library study methods. .This research reveals Character values in Bima in the Mahabarta lakon Dewa Ruci puppet story. The researcher found that a hard figure is not a guarantee of a hard person who has bad character such as honesty, strong metal, moral character, sradha or strong beliefs and feelings sincere people who deserve to be exemplified by the present generation.
\end{abstract}

Keywords: Puppet, Character, Bima, Ancestral Heritage, Adiluwung, Position. 


\section{PENDAHULUAN}

Arus modernisasi membawa perubahan dan kemajuan yang berarti bagi bangsa Indonesia. Dalam era globalisasi ini, arus modernisasi dapat memberikan kemudahan dalam kehidupan bangsa Indonesia dalam satu sisi. Pada sisi lainnya arus modernisasi dapat mengubah jati diri bangsa Indonesia jika salah menyikapinya. Indonesia yang kaya akan keragaman budaya dapat dijadikan sebagai alat untuk menegaskan kepribadian bangsa Indonesia. Salah satu unsur yang dapat menjadi identitas jati dan diri kebudayaan bangsa Indonesia adalah kesenian, terutama kesenian wayang kulit yang menjadi kesenian asli bangsa Indonesia itu sendiri dan menjadi salah satu kebanggan bagi bangsa Indonesia hingga ke Mancanegara.

Budaya wayang merupakan salah satu kesenian tradisional Nusantara yang sampai sekarang masih menghirup hembuskan nafas kehidupannya, terutama di wilayah Jawa, Bali, dan Sunda. Budaya asli bangsa Indonesia, khususnya di Pulau Jawa. Di Jawa, seni wayang memiliki berbagai genre, antara lain wayang golek, wayang beber, wayang wong, wayang klitik, dan wayang kulit. Berdasarkan ceritanya, wayang kulit masih dibagi menjadi beberapa jenis, antara lain wayang kancil, wayang wahyu, dan wayang parwa (Djojosupadmo, 1978).

Wayang merupakan salah satu seni budaya bangsa asli Indonesia yang menonjol di antara berbagai karya budaya lainnya. Wayang berkembang pesat di Pulau Jawa dan Bali. Selain di Pulau Jawa dan Bali, seni pertunjukan wayang juga populer di berbagai daerah seperti Sunda, Sumatera, dan Semenanjung Malaya. Budaya wayang meliputi berbagai seni peran, seni suara, seni musik, seni tutur, seni sastra, seni lukis, seni pahat, dan lain-lain. Wayang juga sebagai salah satu bentuk seni budaya klasik tradisional yang telah berkembang selama berabad-abad. Budaya wayang yang terus berkembang dari zaman ke zaman juga merupakan media penerangan, pendidikan, pemahaman filsafat, serta hiburan. Dalam perkembangannya wayang kulit lebih populer karena wayang kulit mengandung banyak ajaran mulia, kesenian pertunjukan wayang kulit masih dipertahankan dan dilestarikan dalam masyarakat, khususnya masyarakat Jawa dan Bali. Hal ini menunjukkan bahwa masyarakat Jawa dan Bali masih membutuhkan pesan-pesan atau nilai-nilai moral dalam cerita wayang kulit. 
Wayang merupakan tontonan sekaligus tuntunan. Tontonan mengarahkan pada fungsi paedagogis (pendidikan), sedangkan tuntunan merujuk pada arah sebagai sosok karya seni yang mengandung nilai estetis (keindahan/sundaram).

Wayang diturunkan oleh para leluhur secara turun-temurun kepada generasi selanjutnya secara tradisional, wayang merupakan gambaran kehidupan manusia di dunia yang mengandung dua sifat yaitu, ada sifat baik dan sifat buruk. Sebagai contoh, wayang yang memiliki sifat baik adalah Kesatria Pandawa dalam cerita Mahabarata.

Oleh karena itu, wayang oleh para leluhur Jawa dan Bali diharapkan tidak saja menjadi tontonan, tetapi juga bias menjadi tuntunan manusia dalam berperilaku (Rahardjo, 2010:113). Keberadaan wayang sudah berabad-abad sebelum agama Hindu masuk ke Pulau Jawa. Walaupun cerita wayang yang populer di masyarakat masa kini merupakan adaptasi dari karya sastra India, yaitu Ramayana dan Mahabarata. Kedua induk cerita itu dalam pewayangan banyak mengalami pengubahan dan penambahan untuk menyesuaikannya dengan falsafah asli Indonesia. Penyesuaian konsep filsafat ini juga menyangkut pada pandangan filosofis masyarakat Jawa terhadap kedudukan para dewa dalam pewayangan. Para dewa dalam pewayangan bukan lagi merupakan sesuatu yang bebas dari salah, melainkan seperti juga makhluk Tuhan lainnya, kadang-kadang bertindak keliru, dan bisa jadi khilaf.

Hadirnya tokoh Punakawan (Semar/Tuwalen, Gareng/Merdah, Petruk/Sangut, dan Bagong/Delem) dalam pewayangan sengaja diciptakan para budayawan Indonesia (tepatnya budayawan Jawa dan Bali) untuk memperkuat konsep filsafat bahwa di dunia ini tidak ada mahluk yang benar-benar baik, dan yang benar-benar jahat. Setiap mahluk selalu menyandang unsur kebaikan dan kejahatan.

Pada umumnya, masyarakat Jawa dan Bali menggambarkan Punakawan sebagai orang kecil (kelas bawah), sedangkan yang menjadi majikannya adalah seorang bangsawan atau priayi/ para ratu (Suwardi, 2017).

Dalam setiap pagelaran kesenian wayang kulit, cerita wayang selalu berusaha memberikan jawaban mendasar atas berbagai problematika yang terjadi pada kehidupan pribadi maupun umum. Dalam kehidupan pribadi, cerita wayang kulit memberikan jawaban berupa budi pekerti yang tidak hanya bersifat normatif, melainkan aplikatif karena disampaikan dengan contoh-contoh dalam pagelaran 
kesenian wayang, bukan indoktrinatif (gagasan) melainkan edukatif (mendidik) (Solichin, 2011:12).

Pagelaran wayang senantiasa mengandung berbagai nilai kehidupan luhur yang dalam setiap cerita lakonnya selalu memenangkan kebaikan dan mengalahkan keburukan. Hal itu menunjukkan bahwa dalam kehidupan suatu perbuatan baik yang akan menang dan perbuatan buruk akan selalu kalah. Begitu besarnya peran pagelaran wayang dalam kehidupan umat manusia, itu menunjukkan bahwa wayang kulit tidak hanya menjadimedia, tetapi wayang kulit merupakan salah satu identitas jati diri manusia dalam melakukan perbuatan sehari-hari dalam kehidupan. Berangkat dari beberapa pandangan diatas, penulis hendak meneliti tentang nilai- nilai pendidikan dalam cerita wayang kulit lakon Dewa Ruci. Sesungguhnya bagaimana kisah wayang kulit lakon Dewa ruci, apa saja nilai-nilai pendidikan dalam cerita wayang kulit lakon Dewa Ruci, serta apa implementasi dari nilai-nilai tersebut dalam pendidikan. Berbagai nilai yang terdapat dalam cerita wayang kulit dengan lakon Dewa Ruci akan memberikan sumbangan dalam proses pendidikan. Cerita wayang kulit yang telah menunjukkan eksistensinya dalam menghadapi berbagai keadaan zaman, memberikan sumbangan dalam keberhasilan penyiaran agama, sehingga berbagai aspek yang terdapat dalam cerita wayang kulit dapat dikaitkan dengan proses pendidikan. Dalam cerita lakon Dewa Ruci terdapat berbagai aspek pendidikan, karena dalam cerita lakon Dewa Ruci terdapat wejangan yang dapat mengobarkan jiwa untuk menuntut ilmu, berbuat sesuai dengan nilai atau norma yang berlaku, dan menjadi cerita yang memuat ajaran moralitas dan budi pekerti yang sesuai dengan nilai-nilai yang ada, serta memberikan kontribusi yang bermanfaat dalam pendidikan, sehingga menarik untuk dikaji nilai-nilai pendidikan dalam cerita wayang kulit lakon Dewa Ruci.

Cerita singkat Panca Pandawa dan Seratus Korawa berguru kepada Resi Drona. Dalam hal berguru sikap Panca Pandawa selalu jujur berani dan benar, taat dan patuh serta selalu hormat kepada perintah guru (Guru Susrusa), sehingga apa yang diharapkan dalam belajar dapat dicapai terutama dalam Ilmu Danur Dara (ilmu menggunakan panah), sopan santun, sikap susila dan etika. Panca Pandawa akhirnya menjadi keluarga panutan terutama sekali dalam menjalankan ajaran Panca Satya yaitu: Satya Hradaya, Satya Wacana, Satya Laksana, Satya Mitra dan Satya Semaya. 
Satya Hredaya artinya setia pada pikiran, Satya Wacana artinya setia pada kata-kata, Satya Laksana artinya setia pada perbuatan, Satya Mitra artinya setia pada saudara/ teman, Satya Semaya artinya setia pada janji. Sedangkan Seratus Korawa yang bersifat egois dan angkuh selalu ingin menang sendiri dengan tidak punya sikap sopan-santun akibatnya selalu dikalahkan oleh Panca Pandawa dalam hal kualitas pendidikan. Oleh karena itu, lalu mereka memikirkan niat-niat jahatnya untuk menaklukan Panca pandawa. Terutama Sang Bima yang dianggap paling kuat agar bisa ditaklukkan oleh Duryodana. Duryodana minta kepada Resi Drona agar memerintahkan Bima untuk mencari Tirta Kamandalu di dalam lautan dengan tujuan agar sang Bima mati terseret arus gelombang laut.

Resi Drona pun memerintahkan Sang Bima mencari Tirta Kamandaluke dalam laut. Sebelum berangkat Sang Bima tidak lupa minta restu pada ibunya Dewi Kunti, kakanda Yudhistira, serta adik-adiknya. Setelah mendapat restu barulah Sang Bima berangkat. Mendengar keberangkatan Bima tersebut Korawa merasa senang karena yang paling ditakuti tersebut sudah pasti akan mati. Oleh karena Sang Bima menghormati perintah guru dan menjalankan ajaran Satya Laksana sedikitpun tidak punya perasaan curiga selalu tulus menjalankan perintah Guru. Pertama, Bima disuruh mencari Tirta Kamandalu di dalam Sumur Sidurangga.

Namun yang ada di sana dua ekor Naga Besar yang melilit Sang Bima tapi dapat dipotong lehernya kemudian menjelma menjadi Widyadara dan Widyadari. Kepala naga itu dibawa pulang. Kedua, Bima disuruh pergi ke sebuah tempat berupa ladang yang dijaga oleh Raksasa Indrabapu yang ingin mencelakai Bima, namun berkat kesigapan Bima, Indrabapu dipotong lehernya dan dibawa ke Hastina. Seisi kerajaan merasa takut melihat kepala Raksasa Indrabapu yang menyeramkan. Bima disuruh membuang kepala raksasa itu oleh Resi Drona. Ketiga, Bima disuruh mencari Tirta Kamandaluke tengah laut dan tidak boleh memakai perahu. Baik kalau begitu akan saya lakukan, atas dasar kebenaran menjalankan ajaran satya dan guru susrusa. Bima menceburkan dirinya ke laut. Ombak yang begitu besar menyeretnya namun Sang Bima tetap konsentrasi mencari di mana Tirta Kamandalu itu berada.

Dalam keadaan setengah sadar akhirnya Bima mendapat anugrah dari Sang Hyang Nawa Ruci sehingga Bima bangkit kembali. Tak lama kemudian setelah dilihat tidak sadarkan diri lagi akhirnya Bima diberi anugrah lagi dan diberitahu bahwa dia 
telah ditipu oleh Resi Drona dan Duryodana. Bima disuruh masuk ke perutnya untuk mengetahui kehidupan manusia. Akhirnya Bima diantarkan ke tempat Sang Hyang Semara. Sang Hyang Semara memberitahu bahwa Tirta Kamandalu adalah untuk menjaga kehidupan Para Dewata, tetapi dapat diambil oleh Bima. Akhirnya diketahui oleh para Dewata, kemudian Bima direbut dan mati lagi, dan dihidupkan kembali oleh Sang Hyang Nawa Ruci. Bima diganti namanya menjadi Sang Wirota, dia rebut kembali Tirta Kamandalu dari Sang Hyang Bayu dan dibawa pulang ke Astina. Astina menyangkal bahwa yang dibawa Bima bukan Tirta Kamandalu. Guru Drona tidak menghargai jerih payah muridnya akhirnya dikutuk agar diseret oleh air laut. Tidak lama kemudian ada angin ribut menyeret Guru Drona hingga jatuh di laut dan diseret gelombang besar. Melihat kejadian seperti Itu Bima tidak sampai hati membiarkan gurunya terombang ambing oleh ombak. Bima kembali menolong Gurunya. Bima tidak memiliki rasa dendam terhadap Gurunya. Guru Drona tertolong lagi oleh Bima sekalipun dia telah menipu dan membunuh secara halus. Sifat Bima adalah ksama artinya memaafkan.

Rumusan Masalah

Berdasarkan latar belakang masalah di atas, maka penulis mendapatkan beberapa rumusan masalah, diantaranya sebagai berikut:

1. Bagaimana terjadinya pelaksanaan satya laksana bima terhadap guru Drona saat pencarian tirta amerta kamandalu dalam lakon wayang kulit Dewa Ruci ?

2. Nilai-nilai pendidikan karakter apakah yang dapat di teladani atas satya laksana bima guru Drona dalam cerita wayang kulit lakon Dewa Ruci ?

3. Bagaimana relevansi nilai-nilai Satya Bima dalam cerita pewayangan lakon Dewa Ruci pada kehidupan jaman milenial atau masa kini?

Tujuan dan Manfaat

Adapun tujuan secara khusus yang ingin dicapai dalam penelitian ini sesuai dengan rumusan masalah diatas adalah sebagai berikut :

1. Untuk mengetahui kisah bima dan asal usul bima dalam lakon pewayangan Dewa Ruci.

2. Untuk mengetahui akibat dari satya laksana Bima terhadap Guru Drona.

3. Untuk mengetahui akibat dari satya laksana Bima kepada Guru Drona dalam cerita pewayangan Dewa Ruci. 
Penelitian ini diharapkan dapat memberikan informasi dan pengetahuan melalui seni budaya wayang kulit, utamanya adalah membentuk jati diri manusia yang baik melalui nilai-nilai pendidikan dan hasil penelitian ini diharapkan dapat memberikan sumbangan analisis dalam meneliti tentang tokoh bhisma dalam Mahābhārata dan sebagai motivasi untuk para pengkaji naskah kuno seperti Mahābhārata untuk lebih giat lagi menggali nilai-nilai pendidikan yang dapat dijadikan pedoman dalam kehidupan.

\section{METODE PENELITIAN}

Penelitian ini menggunakan metode kualitatif dengan menggunakan analisa deskriptif kualitatif (Moleong, 2010). Penentuan pencarian data ini dilakukan dengan teknik kajian pustaka dimana penulis akan mengkaji suatu naskah utama yaitu Mahābhārata karangan Kamala Subramaniam yang diterbitkan oleh Paramita pada tahun 2003. Selanjutnya, penulisan didukung oleh beberapa sumber referensi lainnya yang berkaitan dengan buku Serat Dewa Ruci. Hal ini diperlukan agar penulis dapat menemukan jawaban atas permasalahan yang diteliti dari berbagai sudut pandang dan mampu menyimpulkan jawaban sebagai titik terang atas segala hal yang dijadikan sebagai rumusan masalah. Triangulasi dengan sumber Triangulasi ini berarti membandingkan dan mengecek balik derajat kepercayaan suatu informasi yang diperoleh melalui alat dan waktu yang berbeda dalam penelitian atau pengamatan lapangan dari analisis kualitatif. Tehnik ini dapat digunakan untuk membandingkan sumber informasi yang diperoleh dari pustaka satu dengan yang lainnya atau dapat pila untuk membandingkaan antara informasi yang ada dari masyarakat atau tokoh melalui wawancara dengan informasi dari isi buku.

Adapun proses analisis data yang digunakan dalam penelitian ini adalah teori semiotika yaitu ilmu tanda, teri hermeneutik yang berarti menafsirkan atau menginterpretasikan dengan tujuan unruk mencapai dan menemukan makna yang terkandung dalam obyek penelitian. 


\section{HASIL PENELITIAN DAN PEMBAHASAN}

Terjadinya Pelaksanaan Satya Laksana Bima terhadap Guru Drona saat Pencarian Tirta Amerta Kamandalu dalam Lakon Wayang Kulit Dewa Ruci

Dalam Serat Dewa ruci menjelaskan pentingnya seorang satya murid kepada guru, seseorang harus yakin terlebih dahulu dengan apa yang akan dicari, sehingga ia tidak bingung dan tersesat. Karena untuk mendapatkan apa yang dicari terkadang orang harus siap berhadapan dengan marabahaya yang mengancam jiwa. Seperti dialog Dewaruci dengan Bima (Durma 21-22), disebutkan:

Lan maninge Wrěkodara ingkang prapta// Dan ia tahu Werkudara yang datang Iya ing kene iki// di sini ini

Akeh pancabaya// banyak marabahaya

Yen nora êtoh pêjah// jika tidak bertaruh nyawa

Sayekti tan prapta ugi// tak akan orang sampai kesini

Ing kene mapani// di tempat ini

Sakalir sarwa mamring// segalanya serba sepi.

Nora urup lan ciptamu paripaksa// Pikiranmu tidak jelas dan memaksa

Sedya kaluhuran// demi menggapai kemuliaan

Kene mangsa anaa// yang tak mungkin ditemukan di sini

Kewran sang Wrêkudara// Werkudara menjadi bingung

Sêsaurira// atas ucapan itu

Dene tan wruh ing gati// karena tidak tahu maksudnya.

Maka dari itu sangatlah penting bagi seorang murid yang sedang menuntut ilmu, untuk Satya Laksana kepada guru yang akan menuntun dan membawa sang mdaurid pada kebenaran. Seperti halnya yang dikatakan oleh Maulana Jalaludin Rumi, apabila seorang murid tidak mendapat bimbingan dari seorang murid, jika diibaratkan dua hari perjalanan akan menjadi perjalanan seratus tahun bagi para pencari. Dengan alasan inilah, seorang murid mutlak diperlukanya seorang pembimbing atau guru dalam menuntut ilmu

Serat Dewa Ruci yang menjelaskan keinginan Bima untuk mencari guru pembimbing, terdapat dalam pupuh Dandanggula (I), pada bait 11-13, terjadi dialog antara Bima dan Gurunya, Resi Drona. Bima menunjukkan sikap hormatnya kepada Resi Drona dengan cara menyembah dan memastikan bahwa Bima akan memenuhi tugas dari Gurunya Drona, yaitu untuk mencari air kehidupan (Swie, 1922).

Bima ingin membuktikan sikap Satya laksana kepada gurunya dan Bima ingin menyucikan hidupnya dengan mencari tirta Amerta Kamandalu atau air kehidupan. 
Atas dorongan itu, ia berusaha mencari Guru yang dapat memberi petunjuk. Akhirnya Bima pun mempercari Guru Drona, dengan penuh keyakinan bahwa Guru Durna bisa memberi wedjangan (petunjuk) kepadanya agar bisa memperoleh air kehidupan. Berikut dialog antara Bima dan guru Drona:

Ebah kagyat kang samya alinggih// Terkejut semua yang hadir Sri narendra Ngastina ngandika// Raja Astina berkata Yayi den kapareng kene// adikku marilah kesini Wrêkudara anjujug// Bima langsung menghadap Dhanyang Durna sigra ngabêkti// Pendeta Durna seraya menyembah Rinangkul jangganira// dirangkul lehernya Babo suteng ulun// wahai anakku Sira sida ngulatana// kau jadi pergi mencari Ingkang tirta pawitra sucining ngurip// air jernih yang menyucikan hidup Yen iku kapanggiha// jika itu kau temukan Nirmala panggih wiseseng urip// Kau akan menguasai hidupmu Wis kawêngku aji kang sampurna// kau kuasai ilmu kesempurnaan Pinunjul ing jagat kabeh// akan unggul di seluruh jagad

Ngaubi bapa bijung// melindungi bapak ibumu

Mulya saking sira nak mami// kemuliaan datang darimu anakku Linuwih ing tri loka// unggul di dalam Triloka Langgêng ananipun// yang kekal abadi Arya Sena matur nêmbah// Arya Sena berkata sambil menyembah Inggih pundi prênahe kang tirta suci// di manakah tempatnya air suci itu Nuntên paduka têdah// mohon aku diberi petunjuk.

Prênahipun kang her adi êning// Di mana tempat air bening itu Rêsi Durna mojar marang Sena// Pendeta Durna berkata kepada Sena Adhuh sutaning sun angger// duhai anakku tercinta Ênggoning kang tuya nung// letak air suci itu Pan ing wana Tikbrasareki// di hutan Tikbrasara Turutên tuduh ingwang// ikutilah petunjukku Sangêt parikudu// harus diperhatikan Nucekakên badanira// itu akan menyucikan dirimu Ulatana soring Gandamadaneki// carilah di bawah gua Gandamadana Ing wukir Candramuka// di gunung Candramuka.

Dialog diatas, menunjukkan perintah yang diberikan Guru Drona kepada Bima untuk mencari air kehidupan. Guru Drona sebagai Guru pembimbing tentunya tidak asal memberi perintah, dia pun pasti memiliki ilmunya, hanya saja dia belum tahu persis apa itu air kehidupan. Resi Durna yang hanya baru tahu teorinya, tapi sudah menyuruh sang murid untuk melaksanakan perintahnya. Dan Bima pun dengan kepatuhan total kepada gurunya berusaha mendapatkan air kehidupan itu. 


\section{Guru Drona sebagai Guru Pembimbing (Jasmani)}

Guru Drona dalam jagad pewayangan, disebut Dahyang Durna, sudah cukup terkenal. Hampir disetiap lakon yang mengisahkan konflik Pandawa dan Kurawa, tokoh ini selalu tampil dan terlibat. Gara-gara menjadi penasihat Kurawa dan banyak menentukan gerak langkah mereka yang dinilai salah, serakah, dan angkara murka, maka Drona benar-benar dicap sebagai tokoh jelek di mata orang Jawa.

Guru Drona adalah satu-satunya Guru besar yang diakui oleh Pandawa dan Kurawa karena telah mengajarkan ilmu jaya kawijayan (Ilmu Kesaktian). Dalam pandangan Bima, Guru Drona merupakan sosok yang istimewa bagi dirinya, karena berkat bimbingannya, Bima berhasil menemukan air kehidupan. Meskipun dalam kisah dinyatakan bahwa Drorna sengaja menjebak Bima agar tewas dalam pencarian tadi, tetapi justru Bima menganggapnya benar-benar sebagai petunjuk dari guru yang dihormati. Berkat kejujuran dan tekad Bima yang demikian besar ia berhasil menemukan kesempurnaan hidup melalui pertemuannya dengan Dewa Ruci yang bermukim di dasar laut. Resi Drona adalah sosok guru yang dianggap sejati bagi Bima, segala perintahnya ditaati, walaupun di dalam hati Drona tertanam benih Kurawa yang jahat, tetapi secara tersirat, sebenarnya Guru Drona telah mengajarkan motivasi mandiri kepada Bima dalam menuntut ilmu.

Kesusatraan India serta Jawa Kuna menjelaskan bahwa, sifat taat seorang murid kepada Gurunya ini merupakan hal yang penting dan disebut dengan guru susrusa. Dalam pandangan hidup bangsa Indonesia yang berasal dari Jawa, hormat kepada Guru ini disebut sembah Guru, yang termasuk lima sembah (panca sembah) serta merupakan dasar pendidikan bagi penduduk di daerah Jawa.

Saat mencari air kehidupan, Bima tidak sedikitpun merasa ragu atas perintah sang guru, ia menjalankan perintah sang guru dengan penuh keikhlasan dan senang hati. Seperti halnya yang diceritakan dalam Serat Dewa Ruci, pada syair pangkur bait ke-1, yang isinya:

Lampahe sang Wrêkudara// perjalanan Bima

Lajêng ngambah praptanireng wana dri// telah sampai di tengah hutan

Ririh ing reh gandrung-gandrung// pelan ia sangat ingin

Sukanireng wardaya// hatinya sangat gembira

Tirta êning pamungkas wekasing guru// mencari air jernih atas petunjuk guru Tan nyipta bayaning marga// tak terpikir bahwa itu berbahaya Kacaryan kang den ulati// ia bahagia atas apa yang dicari 
Naskah tersebut menjelaskan, sikap Bima sangat optimis dan berpikir positif kepada gurunya, sikap ini wajib dimiliki bagi setiap murid yang sedang menuntut ilmu. bahwa hendaklah seorang murid tidak berburuk sangka kepada gurunya dalam setiap perbuatan yang dilakukan. Karena bisa jadi perbuatan itu tampak bagi murid adalah perbuatan mungkar, akan tetapi guru lebih tahu terhadap apa yang ia lakukan.

Bima telah menunjukkan ketaatan dan Satya Laksana yang luar biasa pada perintah gurunya. Dijelaskan bahwa seorang murid juga harus bersikap sabar, dan menjauhkan diri dari perlakuan yang kurang baik, dan jangan menutup diri dan terus berupaya menyertainya dengan menduga tetap ada nilai-nilai positifnya. Dan hendaknya ia tetap menduga terhadap perbuatan baik, Bima menjalankan perintah gurunya dengan penuh totalitas,tak ada keraguan dalam hatinya, yang ada hanya keyakinan akan kebenaran. Ia percaya dan yakin sepenuh hati, bahwa perintah gurunya adalah sebuah kebenaran. Dan ia akan melaksanakan sampai berhasil, dan menaruhkan nyawa. Padahal dalam dirinya sendiri, dia tidak mengetahui apa yang sebenarnya dia cari, dia berusaha patuh kepada gurunya secara total dan melaksanakan semua perintah dan petunjuk gurunya.

Nilai-nilai Pendidikan Karaktek yang dapat Diteladani dari Satya Laksana Bima Terhadap Guru Drona dalam Cerita Wayang Kulit Lakon Dewa Ruci

Religius, Bima membuktikan bahwa sebagai tokoh yang religius ia mampu dan dipersilakan memasuki lubang telinga kiri sang Dewa Ruci terus masuk ke dalam tubuhnya, untuk mendapat wejangan lebih lanjut. Peristiwa ini melambangkan jumbuhing atau manunggaling kawula Gusti, setelah Bima mencapai kesempurnaan hidup, karena sudah tahu tentang hakikat hidup. Orang yang seperti ini, berarti telah mencapai keadaan sadar akan arti sangkan paraning dumadi. Segala ajaran Dewa Ruci dalam hubungan ini melambangkan mustikaning budhi (sumber segala budi pekerti), telah menjadi darah dagingnya. Peristiwa memasuki tubuh sang Dewa Ruci, bermakna bahwa watak sang Bima telah mengalami perubahan penting menuju kebaikan. Contoh dalam kehidupan jaman sekarang adalah sikap dan perilaku yang patuh dalam melaksanakan ajaran agama yang dianutnya, toleran terhadap 
pelaksanaan ibadah agama lain dan hidup rukun dengan agama lain dan melaksanakan kewajiban persembahyangan Puja Tri Sandya sebanyak 3 kali sehari, tidak mengganggu pelaksanaan ibadah/ritual/perayaan pemeluk agama lain dan saling menjaga kedamaian antara pemeluk agama, dan lain-lain.

Jujur, dalam karakter Bima sebagai tokoh yang melambangkan kejujuran terhadap kesetiaan murid kepada gurunya. Kejujuran dan kesetiaan dibuktikan saat Bima diperintahkan mencari Tirta Amerta di tengah samudra. Bima dengan sradha dan keyakinannya mampu membawa air tirta amerta itu. Contoh dalam kehidupan jaman sekarang adalah perilaku yang didasarkan pada upaya menjadikan dirinya sebagai orang yang selalu dapat dipercaya dalam pikiran, perkataan dan tindakan yang dalam ajaran Hindu disebut dengan Tri Kaya Parisudha.

Toleransi, dalam karakter Bima, terdapat karakter toleransi kepada gurunya dibuktikan saat Tirta Amertha sudah diperolehnya kemudian diberikan kepada gurunya, gurunya tidak percaya dan membuang tirta itu yang mengakibatkan Bima mengutuk gurunya supaya dihanyutkan oleh air laut. Tiba-tiba gelombang laut seperti gunung menghayutkan gurunya meskipun demikian Bima tetap mencari dan menolong gurunya. Contoh dalam kehidupan jaman sekarang adalah sikap dan tindakan yang menghargai perbedaan agama, suku, etnis, pendapat, sikap dan tindakan orang lain yang berbeda dari dirinya serta tidak memaksakan pendapat sendiri di atas kepentingan golongan, membiarkan pemeluk agama lain beribadah dengan tenang dan aman, dan lain-lain.

Disiplin, Bima adalah seorang yang sangat disiplin. Bima sangat taat dan patuh menjadi murid Drona. Bima sangat disiplin dalam belajar ilmu pengetahuan yang ditunjukan dengan kemahirannya dalam memakai senjata Gada. Contoh dalam kehidupan jaman sekarang adalah tindakan yang menunjukan perilaku tertib dan patuh pada berbagai ketentuan dan peraturan dan menaati peraturan cara berpakaian yang sopan di tempat tertentu yang formal seperti kantor, universitas dan lain-lain, selalu datang tepat waktu saat bekerja, kuliah ataupun sekolah dan lain-lain.

Kerja Keras, Bima menjalankan perintah gurunya dengan penuh totalitas, tak ada keraguan dalam hatinya, yang ada hanya keyakinan akan kebenaran. Ia percaya dan yakin sepenuh hati, bahwa perintah gurunya adalah sebuah kebenaran. Dan ia akan melaksanakan sampai berhasil, dan menaruhkan nyawa hidupnya. Padahal dalam 
dirinya sendiri, dia tidak mengetahui apa yang sebenarnya dia cari, dia berusaha patuh kepada gurunya secara total dan melaksanakan semua perintah dan petunjuk gurunya. Contoh dalam kehidupan jaman sekarang adalah perilaku yang menunjukan upaya sungguh-sungguh dalam mengatasi berbagai hambatan serta menyelesaikan tugas dengan sebaik-baiknya dan selalu mengerahkan usaha terbaik dalam melakukan sesuatu seperti saat mengerjakan tugas-tugas atau berusaha mencapai impian kita dan lain-lain.

Kreatif, Bima sangatlah kreatif yang bisa dibuktikan dari keahlian Bima dalam peperangan dan Bima mampu mengalahkan musuhnya dengan tehnik perang gulat.. Contoh dalam kehidupan jaman sekarang adalah berfikir dan melakukan sesuatu untuk menghasilkan cara atau hasil baru dari sesuatu yang telah dimiliki dan berusaha untuk terus mengasah kemampuan diri misalnya dalam bidang penulisan karya ilmiah, dengan mencari pengetahuan baru yang dapat melahirkan pemikiran yang inovatif untuk masa yang akan datang.

Mandiri, Dalam kemandiriannya Bima adalah seseorang yang sangat mandiri dibuktikan dari saat ia pergi ke tengah samudera.. Contoh dalam kehidupan jaman sekarang adalah sikap dan perilaku yang tidak mudah tergantung pada orang lain dalam menyelesaikan tugas-tugas serta mampu melaksanakan tugas sendiri tidak selalu mengandalkan orang lain dalam menyelesaikannya.

Demokratis, Karakter demokratis yang dimiliki adalah, sikap yang adil bijaksana kepada guru Drona. Ketika Bima menyaksikan ada angin ribut menyeret Guru Drona hingga jatuh di laut dan diseret gelombang besar,Bima tidak sampai hati membiarkan gurunya terombang ambing oleh ombak. Bima kembali menolong Gurunya . Bima tidak memiliki rasa dendam terhadap Gurunya. Guru Drona tertolong lagi oleh Bima. Sifat Bima adalah ksama artinya memaafkan. Contoh dalam kehidupan jaman sekarang adalah cara berfikir, bersikap dan bertindak yang menilai sama hak dan kewajiban dirinya dan orang lain dan melaksanakan kewajiban tidak hanya menuntut hak saja.

Rasa ingin tahu, Bima mempunyai rasa ingin tahu yang sangat tinggi terbukti saat Bima masuk ke dalam tubuh Dewa Ruci. Rasa ingin tahu itu yang mengakibatkan Bima penasaran dengan apa yang ada dalam tubuh Dewa Ruci. Contoh dalam kehidupan jaman sekarang adalah sikap dan tindakan yang selalu berupaya untuk 
mengetahui lebih mendalam dan meluas dari sesuatu yang dipelajarinya, dilihat, didengar dan mencari kosakata Bahasa Indonesia yang belum dapat dimengerti maknanya dan mencari tahu kebenarannya.

Semangat Kebangsaan, Bima mempunyai rasa kebangsaan yang tinggi, Bima mempunyai jiwa bela negara dan cinta tanah air. Contoh dalam perilaku sehari-hari adalah cara berfikir, bertindak dan berwawasan yang menempatkan kepentingan bangsa dan negara di atas kepentingan diri dan kelompoknya dan mengharumkan nama baik Bangsa Indonesia dengan menjadi relawan atau berprestasi di kancah internasional/mancanegara.

Cinta Tanah Air, Bima seorang pahlawan dari kerajaan Indra Prasta. Bima mampu melawan musuhnya sampai perang Mahabharata selesai. Ini membuktikan Bima sangat mencintai negaranya dan mencintai tanah airnya. Cara berfikir, bersikap dan berperilaku yang menunjukan rasa kesetiaan, kepedulian dan penghargaan yang tinggi terhadap bahasa, lingkungan fisik, sosial, budaya, ekonomi dan politik bangsa. Contoh dalam perilaku sehari-hari adalah mengamalkan nilai-nilai Pancasila dan UUD 1945 dalam kehidupan sehari-hari, karena merupakan pedoman hidup Bangsa Indonesia.

Menghargai apresiasi, Bima sangat menghargai suatu apresiasi terhadap prestasi. Ketika Bima diberikan apresiasi oleh gurunya saat ia mampu mengalahkan raksasa dan naga yang dibunuh oleh Bima. Bima sangat senang mendapatkan apresiasi itu. Sikap dan tindakan yang mendorong dirinya untuk menghasilkan sesuatu yang berguna bagi masyarakat dan mengakui serta menghormati keberhasilan orang lain. Contoh dalam perilaku sehari-hari adalah memberikan pujian kepada adik yang baru bisa memulai sesuatu yang baru baginya, memberikan selamat kepada teman bila mendapat prestasi dan lain-lain.

Bersahabat/Komunikatif, Bima, adalah seseorang yang suka bersahabat dibuktikan dari tidak membedakan sahabat, baik itu kaum bangsawan, brahmana, sudra. Contoh dalam perilaku sehari-hari adalah sikap dan tindakan yang mendorong dirinya untuk menghasilkan sesuatu yang berguna bagi masyarakat dan mengakui serta menghormati keberhasilan orang lain dan melakukan penelitian yang bermanfaat bagi masyarakat, bersikap ramah dan sopan kepada orang tua, teman, tetangga dan lain-lain. 
Cinta Damai, Karakter cinta damai sangatlah teguh dipegang oleh Bima dibuktikan dari ketika Bima mengikuti pembelajaran di pasraman Drona, Bima selalu diperlakukan tidak baik oleh anak-anak kurawa. Bima tidak pernah membalasnya dan selalu menganggap semuanya itu adalah saudaranya. Itu membuktikan bahwa Bima mempunyai sifat cinta damai. Contoh dalam kehidupan sehari-hari adalah sikap dan tindakan yang mendorong dirinya untuk menghasilkan sesuatu yang berguna bagi masyarakat, mengakui serta menghormati keberhasilan orang, dan menyebarkan virus kebaikan kepada orang lain serta tidak membuat ujaran kebencian.

Gigih, Sosok Bima dalam kisah Dewa Ruci, diceritakan sangat senang menuntut ilmu, meskipun dalam pencariannya itu ia kerap kali menemukan rintangan dan godaan, ia tetap berusaha untuk melewati kesulitan itu. Semuanya ia lewati demi tercapainya cita-citanya yaitu menemukan air kehidupan. Rasa semangatnya yang tinggi dan motivasi menuntut ilmu yang tinggi tercermin jelas dalam prilakunya. Contoh dalam perilaku sehari-hari adalah kebiasaan menyediakan waktu untuk membaca berbagai bacaan yang memberikan kebajikan bagi dirinya dan membaca berita yang penting dan dapat memilah bacaan yang benar adanya atau hanya hoax semata.

Peduli Lingkungan, Bima mempunyai karakter yang peduli terhadap lingkungan dibuktikan saat melakukan hukuman pembuangan di hutan Bima sangat menjaga hutan tersebut dari raksasa-raksasa yang hendak menghancurkan. Bima melawan raksasa itu hingga hutan terpelihara dan menjadi rindang. Contoh dalam perilaku sehari-hari adalah sikap dan tindakan yang selalu berupaya mencegah kerusakan pada lingkungan alam di sekitar dan mengembangkan upaya-upaya untuk memperbaiki kerusakan alam yang sudah terjadi dan tidak merusak fasilitas yang disediakan oleh pemerintah, membuang sampah pada tempatnya, ikut bekerja bakti membersihkan lingkungan sekitar.

Peduli Sosial, Bima mempunyai karakter peduli sosial, dibuktikan dari mampu hidup rukun bersama kakak dan adiknya. Bima menjaganya dari orang- orang yang ingin mencelakakan diri dan keluarganya. Contoh dalam perilaku sehari-hari adalah sikap dan tindakan yang selalu ingin memberi bantuan kepada orang lain, masyarakat yang membutuhkan dan turut membantu korban bencana alam. 
Tanggung Jawab, Bima adalah seseorang yang mempunyai rasa tanggung jawab yang sangat tinggi dibuktikan ketika ditugaskan oleh gurunya untuk mencari Tirta Kamandalu. Bima melakukan dengan rasa penuh tanggung jawab dan Bima mampu dan berhasil menemukan. Tirta tersebut. Contoh dalam perilaku sehari-hari adalah sikap dan perilaku seseorang untuk melaksanakan tugas dan kewajibannya baik terhadap diri sendiri, masyarakat, lingkungan (alam sosial dan budaya), negara dan Tuhan Yang Maha Esa serta menjalankan amanah yang diberikan dengan sebaikbaiknya, berani bertanggung jawab apabila melakukan kesalahan dan selalu melaksanakan ibadah.

Bagaimana Relevansi Nilai-nilai Satya Laksana Bima dalam Cerita Pewayangan Lakon Dewa Ruci pada Kehidupan Masa Kini

Pada jaman sekarang terdapat sebuat relevansi nilai nilai Satya Laksana Bima dalam cerita pewayang lakon Dewa Ruci pada kehidupan masa kini. Kata Bhakti dalam kehidupan sehari-hari sering kita dengar dan kita pakai sesuai dengan tujuannya. Secara etimologi kata bhakti dalam kamus besar bahasa Indonesia diartikan tunduk dan hormat atau perbuatan yang menyatakan setia (Kasih, Hormat dan Tunduk ). Karena bhakti berarti tunduk, hormat dan setia, maka dalam berbagai aspek kehidupan kata tersebut dipakai sebuah pernyataan penyampaian rasa bhakti itu sendiri, seperti : bhakti kepada Tuhan yang maha Esa dan para leluhur (tanda penyampaian rasa hormat dan tunduk ), bhakti kepada Nusa dan Bangsa, bhakti kepada orang tua, bhakti kepada guru, bhakti kepada Raja atau pemimpin. Kata bhakti dengan tulisan "Bhakti" bahasa sanskerta berarti bagian, pembagian, penghormatan, bhakti, kesetiaan (Tim Penyusun, 2013). Sedangkan dalam kamus istilah Agama Hindu (Aratana, I Dewa Ketut, 2017) dinyatakan bhakti dari urat kata bha = hormat, sujud, bhakti. Bhakti Marga = jalan bhakti : melaksanakan agama dengan jalan sembahyang, mempersembahkan upakara dan sebagainya. Pengertian bhakti disini sepadan dengan takwa, sedangkan sradha sepadan dengan iman, sehingga istilah iman dan taqwa (imtaq) dalam bahasa yang sudah popular dalam agama Hindu disebut Sradha-Bhakti.

Keyakinan Hindu terhadap Ida sanghyang Widhi wasa, Tuhan Yang Maha Esa tentu berbeda dengan ajaran diluar agama Hindu. Agama Hindu mengajarkan bahwa 
Tuhan itu tunggal, tetapi punya sebutan banyak, (Ekam Sat Wiprah Bahuda Wadanti). Tuhan itu bersifat Nirguna dan Saguna, dapat berwujud/bermanifestasi ke dunia disebut Awatara. Tuhan memiliki ribuan sifat kemahakuasaanNya. Tuhan penggerak Dharma dengan tiga fungsi utama (Tri Murti : Brahma, Wisnu, Siwa), Tuhan sebagai pencipta, pemelihara, pelebur kembali sesuai putaran Dharma. Oleh Karena itu, jika umat Hindu melaksanakan Bhakti/sembahyang ataupun persembahan dapat dilakukan berkali-kali, walaupun Ida Sang Hyang Widhi tunggal, namun memiliki berbagai kemahakuasaan. Sembahyang atau bhakti dapat dilakukan dimana saja, asalkan tempat yang telah disucikan atau dianggap suci dan layak sebagai tempat sembahyang/mebhakti.

Disamping sembahyang kepada Ida Sang Hyang Widhi Wasa, Tuhan Yang Maha Esa, Hindu mengajarkan juga sembahyang kepada Leluhur, karena para leluhur tersebut sudah berjasa memberikan perlindungan kepada turunannya sepanjang hidupnya, bahkan setelah di alam niskala. Mereka yang meninggalkan leluhurnya akan terkutuk, tidak merasa bahagia dalam hidupnya, walaupun tampaknya kaya (paling tidak hatinya selalu terganggu dan ragu-ragu). Obyek utamanya adalah Ida Sang Hyang Widhi Wasa dengan segala kemahakuasaan-Nya (Dewa) dan Sakti-Nya (Dewi), sejumlah manifestasi-Nya, dan para leluhur, baik leluhur yang mempunyai hubungan Vertikal pada setiap umat maupun leluhur Secara horizontal mendapat pengakuan bersama dalam agama.

Pelaksanaan bhakti dapat dilakukan Secara sendiri-sendiri/menyendiri dan bisa juga dilakukan Secara bersama-sama. Dengan kata lain beragama bisa dalam kesendirian dan bisa dalam kebersamaan.

Nilai Moral yang perlu diajarkan pada anak-anak masa kini, adalah sikap saling menghargai. Saling menghargai satu sama lain merupakan salah satu pelajaran/pendidikan moral yang perlu diajarkan pada anak-anak sejak usia dini.

Ajarkan pada anak untuk memiliki sikap menghargai setiap perbedaan dan beri penjelasan pada anak kalau saling menghargai merupakan sikap terpuji dan perbedaan itu merupakan sesuatu yang indah karena setiap orang memiliki cara yang berbeda dalam mencapai tujuan dan menjalani hidup. Nilai moral seperti ini penting untuk diajarkan pada anak supaya mereka mudah beradaptasi ketika berada dilingkungan sosial. Mengajarkan sikap jujur dan jangan berbohong Melihat 
fenomena zaman sekarang, rasanya sulit sekali menemukan orang yang memiliki sifat jujur. Faktor mendasar yang menyebabkan seseorang berbohong adalah kebiasaan pada waktu kecil sehingga terbawa sampai dewasa. Oleh karena itu penting sekali mengajarkan dan menerapkan kebiasaan bersikap jujur pada anak- anak sejak usia dini. Orangtua harus memberikan penjelasan pada anak-anak bahwa bersikap jujur merupakan hal yang sangat penting dan termasuk sikap terpuji yang akan membawa kebahagiaan dalam hidup. Selain itu, berikan penjelasan pada anak kalau kebohongan hanya indah diawal dan akan membawa penderitaan sepanjang hidup. Sekecil apapun kebohongan tetap saja akan membawa dampak yang besar bagi kehidupan. Mengajarkan sikap rendah hati dan suka menolong sesame.

Nilai moral selanjutnya yang penting untuk diajarkan pada anak adalah sikap saling menolong dan rendah hati. Supaya anak mudah mengerti, Anda dituntut untuk tidak hanya memberikan penjelasan secara lisan saja, akan tetapi alangkah lebih baiknya juga memberikan contoh yang bisa dilihat langsung oleh anak seperti menolong orang lain yang sedang kesusahan. Hal tersebut tentunya akan menginspirasi anak untuk mengikuti kebiasaan baik tersebut. Anak-anak pada usia dini cenderung akan mudah meniru setiap perbuatan yang dilihatnya, baik itu perbuatan baik ataupun buruk. Maka dari itu peran orangtua sangat dibutuhkan untuk mengarahkan anak ke jalur yang lebih baik sejak uisa dini. Perilaku dan kebiasaan baik yang diajarkan pada anak akan terbawa sampai usia dewasa

Mengajarkan sikap bertanggung jawab atas apa yang telah diperbuat. Pelajaran moral yang berhubungan dengan tanggung jawab penting sekali diajarkan pada anakanak. Ajarkan pada anak untuk senantiasa meminta maaf apabila melakukan kesalahan terhadap orang lain. Berikan penjelasan pada anak-anak kalau meminta maaf adalah bentuk dari tanggung jawab atas kesalahan yang telah diperbuat. Nilai moral ini akan membentuk pribadi anak yang memiliki sifat rendah hati dan mau mengakui kesalahan sendiri. Mengajarkan sikap menyayangi, saling menyayangi merupakan salah satu sikap untuk menciptakan persaudaraan antar sesama manusia. Ajarkan pada anak bahwa menyakiti orang lain adalah sikap yang salah dan akan berdampak negatif. Anak-anak harus diberi pengertian kalau menyakiti orang lain tidak hanya berupa perbuatan, akan tetapi bisa juga berasal dari perkataan. Kini kita hidup di era modern yang semua hal dapat dilakukan dengan mudah dan simpel. 
Tetapi perubahan dan perkembangan zaman yang tak diikuti dengan perkembangan mental positif manusia tentu malah membuat perkembangan yang seharusnya makin membaik malah menjadi kian memburuk. Khususnya di Indonesia sendiri, Indonesia merupakan salah satu negara berkembang yang memiliki penduduk dalam jumlah yang besar di dunia. Pada era globalisasi ini budaya kebarat-baratan mulai banyak berpengaruh terhadap masyarakat di Indonesia khususnya para generasi muda. Budaya asing yang masuk ke Indonesia tak terkecuali yang bersifat negatif.

Masuknya budaya positif maupun negatif yang tidak didukung dengan mental generasi muda yang baik dapat berpengaruh buruk. Generasi muda tentunya sangat mudah untuk terpengaruh banyak hal. Apabila mereka tidak dapat mengatasi pengaruh buruk dari lingkungan luar mereka, tentunya generasi muda akan kehilangan pribadi baik dan menjadi pribadi yang buruk. Contohnya dalam hal nasionalisme, sebagian generasi muda mulai melupakan nilai-nilai kebangsaan di Indonesia ini. Mereka bahkan tidak dapat menghargai nilai-nilai budaya sendiri. Saat ini marak terjadi pelecehan seksual ataupun pembully-an melalui sosial media. Dari ketiga kasus tersebut dapat disimpulkan bahwa sikap dan mental sebagian generasi muda Indonesia sudah memburuk. Kecurangan yang dilakukan sejak dini dapat menjadi akar-akar korupsi di masa depan. Melihat tabiat buruk sebagian generasi muda Indonesia sekarang, maka apa jadinya negara ini ke depannya? Jika tidak ada revolusi mental yang dilakukan sejak dini, maraknya kasus murid melawan guru, kasus mahasiswa sampai membunuh dosennya sendiri dan kasus lainnya yang sejenis. Oleh karena itu revolusi mental diperlukan untuk merubah tabiat buruk generasi muda menjadi positif.

Pembentukan mental dan karakter dimulai dari lingkungan yang paling dekat dengan tiap individu yaitu lingkungan keluarga dan pendidikan formal. Keluarga berpengaruh besar dalam pembentukan karakter tiap individu, maka dari itu sebagai ayah,ibu, ataupun sesama saudara harus membiasakan kegiatan positif dalam kehidupan keluarga. Selain itu sekolah berguna untuk mendidik dan menyiapkan generasi muda untuk menyongsong masa depan yang lebih baik. Hal baik dan positif yang diterapkan di sekolah akan menjadi kebiasaan generasi muda pada masa depan. Pada akhirnya nasib bangsa ini berada di tangan para generasi muda. Generasi muda akan menggenggam tanggungjawab besar untuk jalannya negara ini pada masa depan. 
Keiklasan/lascarya secara literal dalam bahasa sansekerta memiliki arti keikhlasan. Dalam ajaran Dharma, lascarya berarti sadhana melatih diri sendiri menjadi manusia yang memiliki keikhlasan mendalam. Sebuah jalan yang tersingkat dan terpendek untuk memurnikan kesadaran, adalah melatih diri kita untuk dapat bersikap ikhlas dan penuh kerelaan dalam menghadapi rasa sakit. Ketika kita disakiti orang lain atau tersakiti oleh situasi keadaan, belajarlah untuk menerima dengan keikhlasan sempurna. Kebanyakan manusia dalam perjalanan hidup hanya mau mengalami kebahagiaan saja, tidak mau mengalami rasa sakit dan kesedihan. Padahal mengalami kebahagiaan dan kesedihan laksana musim hujan dan musim kemarau, keduanya datang dan pergi sesuai dengan aliran waktu. Jika kita bersikeras hanya mau mengalami kebahagiaan saja, hal itu tidak saja akan membuat kita terbenam dalam kesengsaraan, tapi juga akan membuat kesadaran menjadi gelap. Tidak pernah ada kehidupan yang sepenuhnya terbebas dari rasa sakit dan kesedihan. Sehebat, sesukses, atau seterkenal apapun seseorang, pasti dalam hidupnya akan pernah mengalami rasa sakit dan kesedihan. Belajarlah untuk tidak protes dan mengeluh. Karena protes dan mengeluh akan membuat kita semakin tenggelam dalam keadaan yang buruk. Belajarlah untuk tidak menyalahkan siapa-siapa, karena tidak membawa jalan keluar, tapi malah akan memperparah keadaan. Semuanya hanya buah dari karma/perbuatan yang datang dari masa lalu. Tidak selamanya kehidupan berjalan menuju arah yang kita inginkan.

Kadang kehidupan justru malah berjalan ke arah yang berlawanan. Mau bahagia dapatnya sengsara, mau dipuji dapatnya dihina. Keadaan seperti ini kita perlu sikap keikhlasan. Disaat seperti itu untuk sejenak tariklah jarak dengan kehidupan duniawi. Artinya kembali ke tujuan asli kita terlahir ke dunia ini, yaitu untuk menyempurnakan kesadaran Atma.

Biarkan rasa sakit dan kesedihan memurnikan kesadaran kita dengan cara menerimanya dengan penuh keikhlasan dan kerelaan. Ketika dalam kehidupan ini kita mengalami kesialan, dicaci-maki, atau nasib buruk lainnya, coba ucapkan kata "tidak apa-apa" berulang kali kepada diri sendiri, sebagai mantra sakral untuk meringankan beban pikiran kita. Untuk menasehati diri kita sendiri agar kita merelakan/lascarya, sehingga kesadaran kita tidak dicengkeram oleh kegelapan pikiran. Kesadaran kita dicengkeram oleh kegelapan pikiran bukan karena kita mengalami kesialan, dicaci- 
maki, atau nasib buruk lainnya, melainkan karena kita menolak mengalami apa yang kita alami tersebut. Dengan merelakan lascarya maka kesadaran kita tidak dicengkeram oleh kegelapan pikiran, dan kita juga sekaligus dapat menyelesaikan karma-karma masa lalu kita. Sedikit ada manusia yang menyadari bahwa ada berkah rahasia spiritual yang indah dibalik setiap rasa sakit yang datang dalam kehidupan. Rasa sakit bisa menjadi jalan singkat dan pendek untuk menemukan kembali diri kita yang sejati, dengan syarat kita dapat menerimanya dengan penuh keikhlasan. Caranya, kapan saja kita merasa tersakiti atau terlukai, belajar untuk tidak lari ke hiburan, makanan, dan sebagainya. Tapi terima rasa sakit dengan penuh keikhlasan dan kerelaan. Ijinkan rasa sakit memurnikan kesadaran kita semakin dalam, semakin dalam dan semakin dalam lagi.

Akan sangat membantu jika kita bisa pergi ke tengah-tengah alam terbuka atau ke sebuah parahyangan suci yang ada sumber mata airnya. Begitu rasa sakit dapat terus dilewati lagi, lagi dan lagi, kesadaran kita terus semakin dimurnikan. Jauh lebih dalam lagi, kapan saja kita merasa tersakiti atau terlukai, belajar agar kesadaran kita tidak dicengkeram oleh rasa sakit, dengan cara melihat dan merasakan rasa sakit serta jejak-jejak kesengsaraan yang dialami oleh orang-orang yang menyakiti atau melukai kita. Dengan cara seperti ini tidak saja kesadaran kita akan bebas dari cengkeraman rasa sakit, tapi kita sekaligus juga dapat bersikap penuh pengertian dan belas kasih kepada orang yang menyakiti atau melukai. Gunakan semua pengalaman kehidupan menjadi sarwa dharma (semuanya dharma), semuanya adalah jalan untuk menemukan kembali diri kita yang sejati. Kesedihan dan kesengsaraan adalah kesempatan untuk membayar lunas hutang-hutang karma masa lalu kita, serta untuk merenungkan kembali tujuan asli kelahiran Atma ke dunia. Kebahagiaan adalah kesempatan untuk menikmati kehidupan sebentar. Hinaan orang adalah masukan untuk belajar rendah hati. Pujian orang adalah kesempatan untuk memotivasi diri.

Kegagalan adalah masukan agar kita segera berubah. Kesuksesan adalah kesempatan untuk menolong orang lain. Dengan cara demikian tidak saja hidup kita akan damai penuh keikhlasan dan kerelaan dalam aliran waktu, tapi sekaligus juga membuat kesadaran kita menjadi terang bercahaya. Ketika dalam kehidupan ini kita mengalami rasa sakit dan kesedihan, itu bukanlah hukuman Tuhan. Ketika kita 
mengalami rasa sakit dan kesedihan, sesungguhnya kita sedang diberi kesempatan spititual yang sangat berharga untuk memurnikan kesadaran kita.

Tapi pemurnian kesadaran ini hanya bisa terjadi kalau kita bisa menerima rasa sakit dengan penuh keikhlasan dan kerelaan. Bukan menolak, mengeluh, apalagi marah melawan dengan rasa sakit. Jika kita dapat menerima rasa sakit dengan keikhlasan dan kerelaan sempurna, hal itu tidak saja membuat kita membayar lunas hutang-hutang karma masa lalu kita, tapi juga membuat kesadaran kita menjadi termurnikan sekaligus tersempurnakan. Dalam kehidupan manusia tidak pernah ada kehidupan yang selalu aman, nyaman dan bebas dari masalah. Jika kesulitan, kesialan atau masalah sudah saatnya datang dalam kehidupan akibat akumulasi karma buruk kita di masa lalu, hal itu akan datang dengan tidak bisa dibendung. Jika disaat-saat seperti itu kesadaran kita dicengkeram oleh perasaan sakit hati, sentimen, marah, benci, dendam, tidak puas atau rasa sedih yang terlalu dalam, itu hanya merupakan sebuah masukan kalau kondisi pikiran kita masih gelap dan sempit, serta kesadaran kita masih berada pada tingkat dimensi kesadaran yang rendah.

Keikhlasan dan kerelaan sempurna membuat kesadaran kita menjadi termurnikan sekaligus tersempurnakan. Praktek keikhlasan dan kerelaan sempurna meredakan cengkeraman emosi-emosi gelap dalam kesadaran kita. Hal ini umumnya merupakan sebuah proses yang membutuhkan waktu. Terutama karena emosi-emosi gelap sudah pekat melekat dalam kesadaran kita dalam jangka waktu yang tidak terhingga panjangnya. Akan terjadi siklus naik-turun dalam kemajuan kita dan itu suatu hal yang sangat manusiawi. Cara yang realistis untuk mengukur kemajuan kita adalah melihat dalam rentang waktu setiap 1 (satu) atau 2 (dua) tahun. Jika kita sudah menjadi orang yang lebih ikhlas dan lebih mudah merelakan, itu berarti kita sudah mengalami kemajuan. Jika dalam jangka waktu bertahun-tahun yang panjang kita terus melatih diri sendiri menjadi manusia yang memiliki keikhlasan mendalam, maka yang pertama kali merasakan hasilnya adalah diri kita sendiri. Secara perlahan-lahan di dalam diri kita akan mengalami kondisi pikiran yang tenang-seimbang dan jernih. Kesadaran kita tidak mudah teracuni oleh rasa sakit, kesedihan, kesulitan, kesialan atau masalah kehidupan. Ini sekaligus berarti kesadaran kita sudah naik pada tingkat dimensi kesadaran yang lebih tinggi. Pikiran kita lebih damai, tenang-seimbang dan jernih. Kita tidak mengalami kesulitan untuk bersikap penuh keikhlasan, merelakan 
dan mengalah. Sehingga, tidak saja setiap buah dari karma buruk kita yang datang dapat mengalir tanpa hambatan, artinya kita dapat menghadapinya dengan kerelaan, tabah dan tahan menderita, untuk kemudian buah-karma buruk itu terselesaikan. Serta sekaligus juga menghindarkan kita dari kemungkinan jalur kehidupan yang lebih kacau atau berbahaya, sehingga hidup kita sendiri juga cenderung menjadi lebih tenang dan damai. Dimana hal ini sesungguhnya juga adalah untuk menolong diri kita sendiri.

Kita hendaknya dapat menyadari hal ini dan menciptakan keberkahan bagi diri kita sendiri dan sekaligus menciptakan keberkahan bagi orang-orang lain disekitar kita. Kenyataan sejati setiap manusia adalah kesadaran Atma yang penuh kedamaian. Tubuh fisik dan tubuh pikiran-perasaan, hanyalah bungkus-bungkus luar dari kenyataan sejati manusia. Ini berarti sesungguhnya manusia tidak perlu mencari kedamaian, kita hanya perlu membuka lapisan-lapisan pembungkus luar Atma, yaitu tubuh fisik dan tubuh pikiran-perasaan. Caranya dengan "istirahat" dari segala bentuk konflik pertempuran dualitas pikiran di dalam diri. Pikiran mulai belajar untuk "istirahat" disaat tekun melatih diri sendiri untuk memiliki keikhlasan mendalam. Pikiran yang sering-sering istirahat inilah yang akan mengantar kita untuk bertemu intisari diri sejati, kesadaran Atma, yang penuh kedamaian.

Bakti kepada guru harus dimiliki pada siswa masa kini. Tanda siswa hormat dan bhakti tehadap gurunya adalah, adanya rasa malu jika berbuat salah dan mengagumi sang guru serta tidak pernah menebar kesan negatif terhadap guru. Hal inilah yang harus diwujudkan pada pendidikan di sekolah masa kini.

Guru yang disegani menandakan guru tersebut ada wibawa dan berkualitas. Sikap negatif yang perlu dihindari oleh antara lain : Egois termasuk sifat negatif yang perlu dihindari. Siswa yang memiliki sifat "keakuan" yang tinggi pasti tidak disenangi oleh guru maupun temannya. Banyak siswa sekarang "gila kesombongan kekayaan orang tuanya" sangat mudah merasa tersinggung oleh perlakuan guru maupun rekan sejawatnya. Ia sering merasa kecewa dan berani melawan gurunya. Bahkan merasa lebih unggul dari gurunya. Jika ada guru yang lebih muda, energik, dan kreatif, ia sering merasa tidak mengormati karena telah merasa lebih pintar karena terlebih dulu mengakses lewat media internet. Maka dari itu rasa bhakti harus ditamankan kepada guru dari sejak dini baik di sekolah maupun di luar sekolah. 


\section{KESIMPULAN}

1. Kisah wayang kulit lakon Dewa Ruci digambarkan oleh Bima atau Arya Sena yang mempunyai semangat untuk menuntut ilmu dan mencari jati dirinya. Dalam cerita ini juga terdapat intisari sang Bima bertemu dengan guru sejati yaitu Resi Drona yang mengajarkan tentang manusia seutuhnya, sehingga pelajaran yang berharga didapatkan setelah perjalanan yang sangat panjang dan mendapat berbagai rintangan demi mematuhi perintah dari gurunya.Dalam perjalanannya Bima bertemu dengan raksasa Rukmuka dan Rukmakala di gunung Candramuka dan Naga besar di tengah laut. Pada akhirnya sang Bima bertemu dengan Dewa Ruci di tengah samudera yang berwujud anak kecil yang bermain di atas air laut. Bima masuk ke dalam tubuh sang Dewa Ruci melalui telinga kiri yang kemudian menerima ajaran tentang kenyataan.

2. Cerita wayang kulit lakon Dewa Ruci mengandung nilai-nilai pendidikan yang penting bagi proses pembelajaran dalam berbagai aspek kehidupan, diantaranya adalah nilai pendidikan moral dan nilai pendidikan budi pekerti. Nilai-nilai yang dapat diterapkan dan diajarkan dalam pendidikan pada umumnya memiliki dasar yaitu moral dan budi pekerti, yang meliputi ajaran bagi peserta didik memuliakan dan menghormati guru, sikap rendah hati terhadap ilmu guru, dan memiliki kesungguhan hati dalam menuntut ilmu dari guru. Dengan demikian, maka tingkah laku peserta didik akan bercirikan kemuliaan.

3. Implementasi atau penerapan dari nilai-nilai cerita wayang kulit lakon Dewa Ruci dapat terlaksana apabila peserta didik dapat meniru dan menerapkan sifat-sifat bijak atau mulia sang Bima dengan cara mematuhi guru, menjalankan apa yang diperintah guru, sopan santun dan bertingkah laku yang baik kepada guru. Nilainilai cerita wayang kulit lakon Dewa Ruci dalam pendidikan didasari dengan nilai pendidikan moral dan budi pekerti. Peserta didik dibekali dengan ajaran-ajaran mulia dari cerita wayang kulit lakon Dewa Ruci yang menjadikan peserta didik pada umumya lebih giat untuk menuntut ilmu dan bekerja keras, hidup rukun, jujur, ikhlas, taat kepada guru, teguh dalam pendirian, mempunyai sikap hormat, dan kesabaran. 


\section{DAFTAR PUSTAKA}

Aratana, I Dewa Ketut, dkk. (2017). Pendidikan Agama Hindu dan Budi Pekerti. (T. E. Duta, Ed.). Bali : Penerbit Duta.

Djojosupadmo, M. . (1978). Wayang: Asal-usul, Filsafat dan Masa Depannya. Jakarta : CV Haji Masagung.

Moleong, L. (2010). Metodelogi Penelitian Kualitatif. Bandung: PT Remaja Rosdakarya.

Suwardi, E. (2017). Antropologi wayang: Simbolisme, mistisisme, dan realisme hidup. Jogjakarta.

Swie, T. K. (1922). Dewa Ruci. Surabaya: Paramitha.

Tim Penyusun. (2013). Swastikarana Pedoman Ajaran Agama Hindu Dharma. Jakarta: Parisada Hindu Dharma Indonesia. 